\title{
Non-invasive prenatal diagnostic test accuracy for fetal sex using cell-free DNA a review and meta-analysis
}

\author{
Caroline F Wright ${ }^{1}$, Yinghui Wei ${ }^{2}$, Julian PT Higgins ${ }^{2}$ and Gurdeep S Sagoo ${ }^{{ }^{*}}$
}

\begin{abstract}
Background: Cell-free fetal DNA (cffDNA) can be detected in maternal blood during pregnancy, opening the possibility of early non-invasive prenatal diagnosis for a variety of genetic conditions. Since 1997, many studies have examined the accuracy of prenatal fetal sex determination using cffDNA, particularly for pregnancies at risk of an $X$-linked condition. Here we report a review and meta-analysis of the published literature to evaluate the use of cffDNA for prenatal determination (diagnosis) of fetal sex. We applied a sensitive search of multiple bibliographic databases including PubMed (MEDLINE), EMBASE, the Cochrane library and Web of Science.

Results: Ninety studies, incorporating 9,965 pregnancies and 10,587 fetal sex results met our inclusion criteria. Overall mean sensitivity was $96.6 \%$ (95\% credible interval $95.2 \%$ to $97.7 \%$ ) and mean specificity was $98.9 \%$ ( $95 \% \mathrm{Cl}=98.1 \%$ to $99.4 \%)$. These results vary very little with trimester or week of testing, indicating that the performance of the test is reliably high.

Conclusions: Based on this review and meta-analysis we conclude that fetal sex can be determined with a high level of accuracy by analyzing cffDNA. Using cffDNA in prenatal diagnosis to replace or complement existing invasive methods can remove or reduce the risk of miscarriage. Future work should concentrate on the economic and ethical considerations of implementing an early non-invasive test for fetal sex.
\end{abstract}

Keywords: Cell-free fetal DNA, Meta-analysis, Non-invasive prenatal diagnosis

\section{Background}

Knowledge of the genetic status of the fetus in an ongoing pregnancy gives couples the power to make an informed decision about their unborn child. When a fetus is known to have a particular genetic abnormality, a decision may be made either to choose termination or to continue with the pregnancy and take steps to provide appropriate care for the newborn child. Prenatal testing falls into two categories: screening and diagnosis. Prenatal screening is offered to all pregnant women as part of routine prenatal care to determine if the fetus is at substantial risk of having a particular disorder such as Down Syndrome or sickle cell anaemia. In cases deemed to be at high risk, prenatal diagnosis is offered to provide

\footnotetext{
*Correspondence: gurdeep.sagoo@phgfoundation.org

'PHG Foundation, 2 Worts Causeway, Cambridge, UK

Full list of author information is available at the end of the article
}

a definitive diagnosis and determine whether the fetus has inherited a disorder.

Prenatal genetic diagnosis is often used where there is a family history of a sex-linked disease. Most sex-linked diseases are recessive $\mathrm{X}$-linked diseases caused by a particular mutation on the $\mathrm{X}$ chromosome. The disease is normally manifested only in males, who carry a single $\mathrm{X}$ chromosome, whilst in females the normal allele on the second $\mathrm{X}$ chromosome compensates for the diseased allele. The most common X-linked recessive diseases include haemophilia (a blood clotting disorder) and Duchenne muscular dystrophy (a progressive muscle wasting disease), although numerous others can result in severe conditions. Whilst each disease is individually relatively rare, it has been estimated that in combination they occur in around 5 in 10,000 live births [1].

In the UK, sex-linked diseases are usually diagnosed through referral to a clinical geneticist when there is a known family history of a particular disease. Although

\section{() Biomed Central}


fetal sex can often be determined using an ultrasound scan of the fetus in the second or third trimester, a definitive prenatal diagnosis can only be made through invasive testing in which a sample of fetal cells is physically removed from the uterus for genetic analysis, using either chorionic villus sampling (CVS) at 11-14 weeks gestation, or amniocentesis from 15 weeks gestation. Both these invasive techniques carry a small but significant risk of miscarriage (1-2\%) [2] and although currently the gold standard for prenatal diagnosis, many women are reluctant to undergo invasive testing. However, there are substantial advantages to earlier diagnosis. Where future management might involve a decision to terminate the pregnancy, early termination carries fewer risks (being medically induced or involving surgical vacuum aspiration), whilst late termination (at more than 14 weeks) may require the induction of labour, potentially causing significantly greater physical, emotional and psychological complications.

Due to the risk of miscarriage with these traditional prenatal diagnostic methods, enormous interest has arisen in the field of non-invasive prenatal diagnosis (NIPD). In 1997, Lo et al. [3] demonstrated the presence of fetal DNA in the maternal blood, opening the possibility that a simple blood test could provide a noninvasive method for prenatal diagnosis. Fragments of cell-free fetal DNA (cffDNA) originating from the placenta are detectable in the maternal blood stream [3] from 5 weeks gestation until birth [4], when they are rapidly cleared from the circulation and are undetectable within 2 hours [5]. It has been proposed that cffDNA could be used for non-invasive prenatal diagnosis. However, cffDNA only comprises around $3 \%$ to $6 \%$ [4], although up to $10 \%$ has also been reported [6], of the total cell-free DNA in the maternal circulation during pregnancy, the rest being maternal in origin. Therefore, distinguishing, or ideally isolating, fetally derived cell-free DNA in an overwhelming background of maternal DNA is a significant technical challenge due to the high level of molecular similarity between it and the maternally derived cell-free DNA. As a result, a number of different protocols have been developed to extract the cell-free DNA from a blood sample and analyze it for fetal specific sequences, usually with real time quantitative polymerase chain reaction (qPCR).

To date, the most advanced application of cffDNA for prenatal diagnosis is fetal sex determination for pregnancies at high risk of an X-linked disease (or certain masculinising endocrine disorders), in order to reduce the need for invasive testing. This is achieved through selective amplification and detection of $\mathrm{Y}$ chromosome sequences not otherwise present in the mother, most commonly the sex determining region Y (SRY), but sometimes using the testis specific protein Y linked 1 (also known as DYS14).
The fetus is presumed to be female if no $\mathrm{Y}$ chromosome DNA can be detected. This technology is already being translated into a clinical setting and is used routinely in some clinics in the UK and elsewhere, and has been shown to reduce the need for invasive testing by $45 \%$ [7]. In addition, several companies currently offer commercial mail-order fetal sexing using cffDNA from a home finger prick sample.

Since 1997, a number of large studies examining the accuracy of prenatal fetal sex determination using cffDNA have been published $[8,9]$ as well as many smaller ones (reviewed by Avent \& Chitty [10]). Devaney et al. [11] have recently published a systematic review and metaanalysis documenting the overall test performance of non-invasive fetal sex determination using cffDNA including data from 57 studies and approximately 6,500 pregnancies. This review was limited however to English language publications and only searched for journals listed in PubMed. Here we report our review and meta-analysis of the wider literature in order to further evaluate the use of cffDNA in the maternal circulation for non-invasive prenatal determination of fetal sex.

\section{Methods}

\section{Eligibility of studies}

We sought all studies in which Y chromosome cell-free fetal DNA (not fetal cells) was extracted from a maternal blood sample and used for sex determination. Pregnant women participating in the studies had to be greater than 5 weeks gestation [4]. The gold standard against which non-invasive prenatal diagnosis of fetal sex is measured is the baby's sex on examination at birth, although we also included studies in which it was determined during pregnancy by amniocentesis or CVS. We considered only studies in which data were presented that allowed a cross-tabulation of sex determination for cffDNA against the reference standard, permitting estimation of sensitivity and specificity.

\section{Search strategy}

We applied a sensitive search of multiple bibliographic databases in March 2010 using text words and MeSH terms, adapting them for each different database. The databases searched and the search terms used in PubMed are listed in the supplementary information. The search was not limited to English language publications or publication type. A filter for diagnostic studies was not applied. Investigators in the field were also contacted for any data not explicitly included in the publications. No reference was made to gender or sex in our search strategy, as many studies that focus on using cffDNA for alternative diagnoses (e.g. $\mathrm{RhD}$, aneuploidy, inherited single-gene disorders, pre-eclampsia, etc.) also test for fetal sex as part of their 
protocol. However, we excluded the small number of studies using massively parallel sequencing for Down Syndrome [12,13] or fetal profiling [6] and looked only at targeted tests.

We attempted to identify cumulative papers which reported data from the same dataset, and contacted authors to obtain clarification of the overlap between data presented in these papers, in order to prevent test data from the same women being analyzed more than once.

\section{Study selection}

All relevant articles identified by the search were scanned on the basis of title, keywords and abstract (where available). Articles were rejected on the initial screen if the reviewer $(\mathrm{CW})$ could determine that the article clearly did not match the eligibility criteria or if the study was published before cffDNA was discovered (1997) [3]. Where a title or abstract could not be rejected with certainty, the full text of the article was obtained for evaluation. The full texts of all relevant articles identified by reference searching were also obtained. Two reviewers (CW and GS) then independently assessed the eligibility of studies for inclusion in the review. If disagreements were not resolved by discussion, a third reviewer $(\mathrm{JH})$ was consulted. Figure 1 presents the number of articles identified by our search strategy along with the process of selecting studies into our review.

\section{Data collection}

We followed methods suggested by the Cochrane Screening and Diagnostic Tests Methods Group [14]. The
PRISMA checklist is attached as Additional file 1. Data were extracted independently by two reviewers, one onto a pre-piloted paper data extraction form (GS) and one onto an equivalent computer database in Microsoft Excel $(\mathrm{CW})$. Differences between extracted data were resolved by discussion and, if necessary, through consultation with a third reviewer $(\mathrm{JH})$. All reviewers participating in the study participated in the pilot of the data extraction form with 10 randomly selected articles.

We extracted descriptive data on primary author, year of study, journal of publication, number of participants including information on gestation, methods used for DNA isolation and preparation where available including blood sample volume, cffDNA sequence detected and the detection method used. We examined each included study for potential major threats to validity. Attempts were then made to obtain any missing or unclear data by contacting the authors of each article.

For each study, we extracted a $2 \times 2$ contingency table in which all individuals were classified as falling into one of the following categories: true positive (TP), false positive (FP), true negative (TN) or false negative (FN), according to the test results. We took a true positive to mean the test-detected presence of $\mathrm{Y}$ chromosomal material in a confirmed male baby; conversely, a true negative was the non-detection of any $\mathrm{Y}$ chromosomal material (plus the detection of control material) in a confirmed female baby. Where available, we also extracted the number of tests with inconclusive or uncertain result, though this information was not used in the formal meta-analysis.

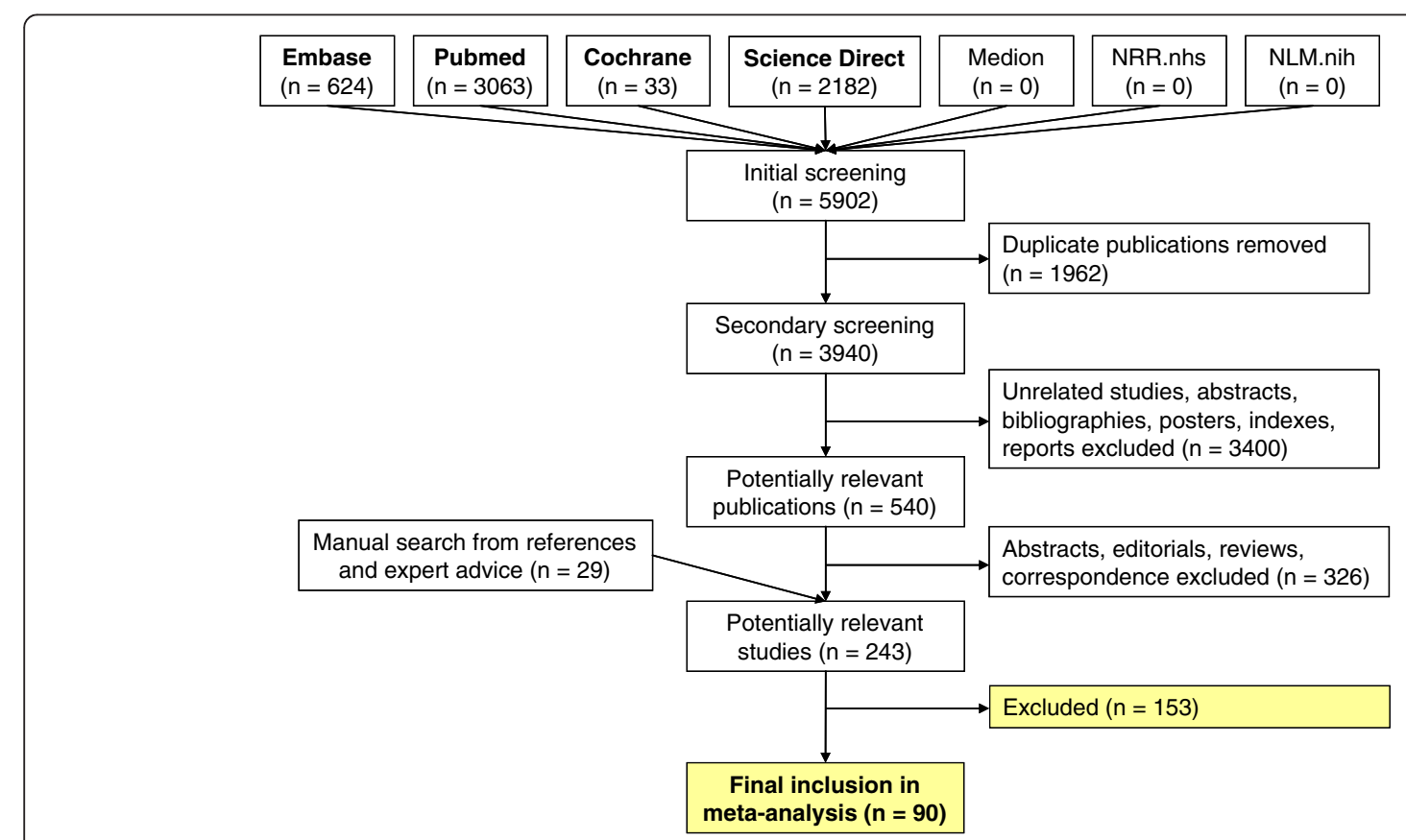

Figure 1 Flow chart of studies identified by the search strategy and the process of eligibility and inclusion. 
Some of the test results were recorded with specified trimester $(1,2$ or 3$)$ and a few of the data were recorded every prenatal week from the $5^{\text {th }}$ to $13^{\text {th }}$ week. The remaining (majority) test results were recorded without specifying in which trimester or week the test was undertaken. The primary dataset contained one $2 \times 2$ table from each study.

\section{Data analysis}

We performed meta-analysis to estimate summary sensitivity and specificity using a bivariate model [15]. This jointly analyses each sensitivity and specificity pair, incorporating the anticipated negative correlation between them through a random-effects approach [15]. The model has two levels. At the first level, the numbers of true positives and true negatives are assumed to follow independent binomial distributions with parameters representing sensitivity and specificity, respectively; at the second level, the logit transformations of sensitivity and specificity are assumed to follow a bivariate normal distribution across studies, which allows for heterogeneity and for the correlation between sensitivity and specificity. We derived prediction intervals from the results of the analysis [16]. Forest plots of sensitivity and specificity used an asymptotic standard error and an assumption of normality on the logit scale. We used these approximate results to assess the contribution of each study to the total heterogeneity for sensitivity and specificity separately, as described by Thompson [17], in order to inform sensitivity analyses.

We performed further bivariate meta-analyses to investigate whether the accuracy of cffDNA testing changes over time during a pregnancy. A second dataset was constructed to examine the possible effect of trimester on test accuracy. Only studies providing specific information on trimester of test were included in this dataset. We analyzed data from each trimester separately, and compared formally them using a metaregression analysis with a categorical covariate representing trimester. A third dataset was constructed to examine the possible effect of week on test accuracy. Only studies providing specific information on the week of the test within the first trimester were included in this dataset; $2 \times 2$ tables in which there were no true males or no true females were omitted. We again used bivariate meta-regression, with a linear effect of week on the logit scale. We used posterior summary statistics for coefficients in the regression to illustrate fitted changes in sensitivity and specificity from five to 13 weeks.

\section{Investigation of heterogeneity}

To investigate the variation in diagnostic accuracy across the studies, we performed meta-regression by incorporating covariates into the bivariate model. In order to assess different techniques used for testing, we used as covariates blood sample (recorded as plasma or serum), sequence detected (SRY or DYS14 or other), detection technique (qPCR or other), extracted blood volume, publication year. Covariates were incorporated into the model through the second level, such that the logit sensitivity and logit specificity were separately regressed on the available covariates. We chose plasma, SRY, and qPCR as baselines for the categorical covariates; the coefficients for these covariates are therefore the comparison of other categories with the baseline. We performed the analyses both with all covariates included simultaneously in the model, and with each covariate included one at a time. Although there were very few instances of multiple versions of the test being used within a study, if women were tested on more than one covariate, we selected data from plasma in preference to serum, and SRY in preference to DYS14 as they were the most commonly reported. We did not evaluate these differences, due to a combination of lack of power and lack of cross-tabulated data.

There were some missing data in both categorical and continuous covariates. We employed multiple imputation techniques to impute the missing, making a 'missing at random' assumption. A missing value for a categorical variable was imputed from a categorical distribution with parameter $p=1 / c$, where $c$ is the total number of different categories of the variable. A missing value for a continuous variable was imputed from a normal distribution with mean and standard deviation equal to those observed for that variable from non-missing values.

\section{Implementation}

The estimates of sensitivity and specificity from the bivariate model as well as the coefficients for the covariates were computed in a Bayesian framework using Markov chain Monte Carlo simulation with publicly available software (WinBUGS) [18]. We added 0.1 to empty cells in the $2 \times 2$ tables. Prior distributions were selected so as to be vague in order to emulate a frequentist analysis: normal with mean 0 and precision 0.00001 for means and coefficients, and wishart(R, df), with $\mathrm{R}=$ identify matrix and $\mathrm{df}=2$ for between-study covariance matrices. For the main analyses we report results based on 10,000 draws of the Markov chain, of which the first $10 \%$ were discarded as burn-in. For meta-regression analyses we used 50,000 draws, of which the first 10\% were discarded. In all analyses, trace plots for the Markov chain show good mixing of the chains, confirming the convergence of Markov chains to their posterior distributions. Credible intervals from these analyses may be interpreted approximately as confidence intervals. Forest plots were drawn using Review Manager [19]. 


\section{Results}

\section{Study characteristics}

Ninety studies [3,4,7-9,13,20-103], incorporating 9,965 pregnancies, were identified that met the eligibility criteria (Additional file 2: Table S1). Fifty studies were located in Europe [3,7,8,20,25-27,29-32,35,37-40,42,4648,50,52,53,57,59-81,94,98,103], 26 from Asia [4,9,23,24, 28,34,36,44,54-56,58,82-86,88,89,91-93,96,100-102], eight from North America [13,21,22,43,51,87,97,99], two from multiple locations $[49,90]$ and a further four from around the rest of the world $[33,41,45,95]$. Gestational ranges for the pregnant women varied across the studies, as did the amount of blood taken and the volume actually used for extracting DNA (see Additional file2: Table S1). The vast majority of studies extracted DNA from blood plasma $(\mathrm{n}=74)$, with nine studies using blood serum [20,23,35, $50,59,64,77,78,97]$, five studies using both plasma and serum $[3,4,65,95,103]$, and two studies not stating which was used $[7,62]$. Real-time quantitative (q) PCR was the most commonly applied detection technique $(n=61)$, with nested PCR used in 15 studies [25,28,34,45,56,58, $62,72,76,85,93,96,100,102,103]$, standard PCR used in a further eleven studies [3,20,23,24,29,31,65,84,88,95,101], and other methods used in three studies $[47,55,82]$. SRY alone was used for fetal sex determination in 49 studies, DYS14 alone in 17 studies [3,9,13,23,28,33,41,42,46,49, $57,58,65,68,76,100]$, both SRY and DYS14 in a further five studies [7,27,32,40,69], with 19 other studies [20,21,24, $31,43,51,62,63,72,77,82,84,87,88,91,94,97,101,102]$ using different markers including amelogenin $(n=6)[31,62,63$ $, 72,91,102]$ or a combination of markers. Only four studies specifically recorded inconclusive results or failed tests $[7,27,29,52]$. We excluded from the meta-analysis data from studies that had no record on foetus sex.

In total we had available $1152 \times 2$ contingency tables from the 90 independent studies, containing 10,587 fetal sex test results. In order to create our primary data set of one table per study, we made the following decisions. First, where trimester information was available for a study but when different women were tested in different trimesters, we summed cell counts across trimesters to obtain the total (82 studies). In one study, results for the same women were reported for each trimester separately. For this study we selected data from the first trimester only. In seven studies, more test results were reported than there were women (i.e. at least some women contributed multiple tests) and we were unable to obtain woman-specific test results. For these studies, we included all test results in the analysis, assuming independence of test results within the study. We acknowledge that this may have resulted in some spurious precision, but the proportion of information in the meta-analysis to which this applies is small.
The second dataset (investigating the effect of trimester) comprises $522 \times 2$ tables of test results from 35 studies incorporating 4,467 fetal sex test results where the trimester of testing was specified: 26 studies contributed tables from the first trimester, 15 from the second and nine from the third. The third dataset (investigating the effect of week) comprises $552 \times 2$ tables from 13 studies covering 1,001 fetal sex test results where the week of testing during the first trimester was specified.

\section{Sensitivity and specificity}

Study-level estimates of sensitivity and specificity for all studies are presented in Figure 2. Figure 3 gives a graphical display of these results, with sensitivity (true-positive rate) on the vertical axis and the 1 -specificity (falsepositive rate) on the horizontal axis. Most of the points cluster around the top left of the graph, indicating the high accuracy of the test. The prediction interval illustrates the upper and lower limits of where any future pair of sensitivity and specificity is expected to lie.

In the primary bivariate meta-analysis, involving 90 studies with 10,587 tests, average sensitivity was $96.6 \%$ (95\% CI from $95.2 \%$ to $97.7 \%$ ) and average specificity was $98.9 \%$ (95\% CI from $98.1 \%$ to $99.4 \%)$. Table 1 shows the summary estimates from these bivariate meta-analyses, along with corresponding results from separate analyses for each trimester when this information was available. Average sensitivity and specificity did not vary markedly by trimester (see Table 1 ). Test accuracy was marginally higher in the second trimester, but no statistically significant differences were found in the meta-regression.

Two studies contributed substantially to heterogeneity in sensitivities across studies [22,26]. After excluding these studies from the bivariate analysis, overall sensitivity and specificity were very similar. A more marked effect was seen for the third trimester on omission of these studies, in which sensitivity increased from $96.6 \%$ to $97.8 \%$ (95\% CI from $92.2 \%$ to $99.7 \%$; prediction interval from $65.4 \%$ to $100.0 \%$ ), and specificity from $99.0 \%$ to $99.4 \%$ (95\% CI from $96.4 \%$ to $100.0 \%$; prediction interval from $87.7 \%$ to $100.0 \%)$.

A small, but not statistically significant, improvement in diagnostic test accuracy can be seen over prenatal week (from 5th to 13th) in Additional file 2: Table S2, based on the limited data available. At week 5, the sensitivity and specificity are 93\% (95\% CI from $84 \%$ to $98 \%$ ) and $95 \%$ (95\% CI from $87 \%$ to $99 \%$ ) respectively; at week 13, the sensitivity and specificity are $98 \%$ (95\% CI from 95\% to 99\%) and 99\% (95\%CI from 96\% to $100 \%)$ respectively. The odds ratio for sensitivity and specificity are 1.19 and 1.21 per additional week respectively. 


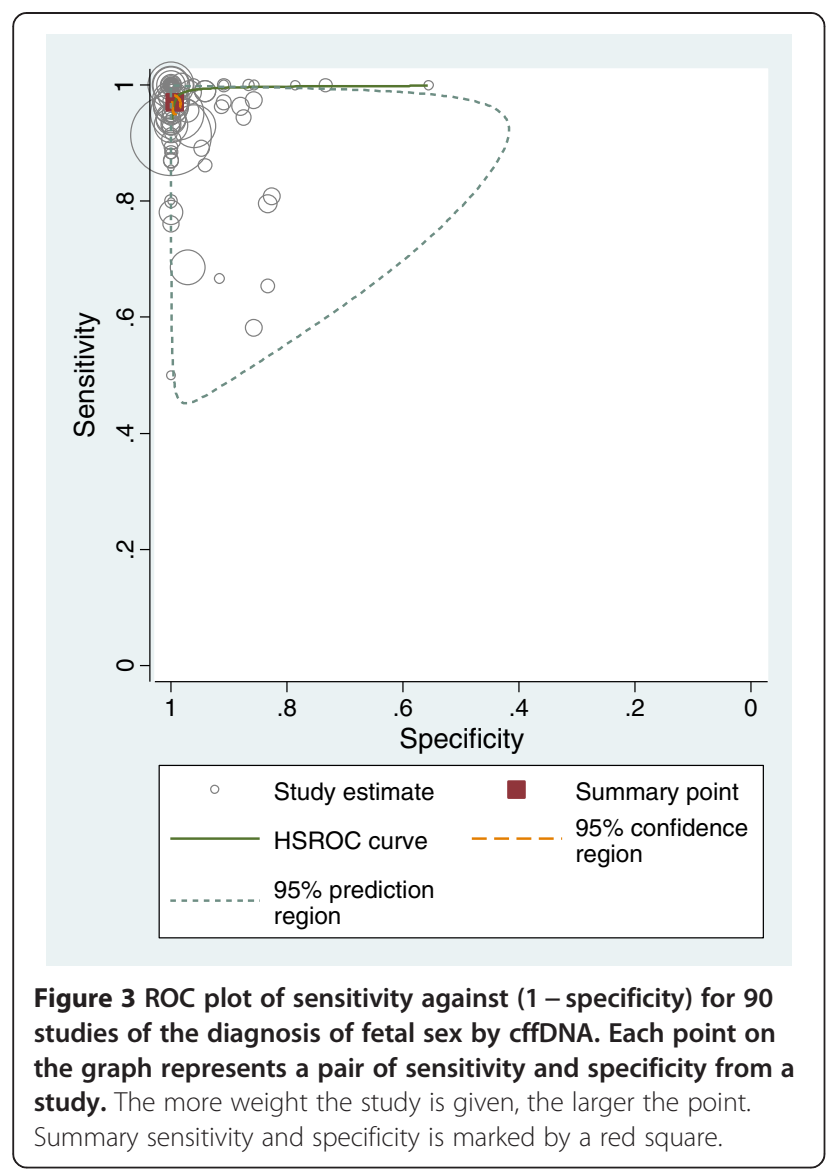

Of the four studies that reported inconclusive results or failed tests, failures represented $11-24 \%$ of tests, these pregnancies were generally re-tested at a later gestational age using a second sample $[7,27,29,52]$. There were several reported reasons for inconclusive, false negative and false positive results including blood samples not being processed appropriately within 48 hours of collection, poor quality blood serum or plasma, variable or low concentrations of cffDNA within the maternal blood samples collected and tested, and the diagnostic threshold used to determine fetal sex.

\section{Investigation of covariates}

Summary statistics for the analyses of covariates and results of the meta-regression analyses investigating other covariates in the primary data set (one $2 \times 2$ table per study) are shown in Additional file 2: Table S3. The use of serum for DNA extraction rather than plasma may increase the accuracy of the test; in unadjusted models, the odds ratios for serum versus plasma are 4.8 (95\% CI 1.2 to 20.7 ) and 6.2 (95\% CI 0.84 to 77 ) for sensitivity and specificity, respectively. These correspond to improvements in sensitivity from $96 \%$ to $99 \%$, and in specificity from $99 \%$ to virtually $100 \%$. There was no discernable difference between using SRY or DYS14 as the DNA marker for fetal sex. The use of qPCR improved specificity compared with other lab-based detection techniques (though note that no studies using next generation sequencing platforms were included). The other lab techniques (including conventional PCR and nested PCR) decrease the sensitivity and specificity to $95 \%$ and $96 \%$, respectively. Increasing the volume of blood that DNA is extracted from may increase both the specificity and sensitivity. Finally, there is an indication of an improvement in sensitivity over time.

\section{Discussion}

This review and meta-analysis of non-invasive prenatal determination of fetal sex using cffDNA in maternal blood, incorporates 10,587 tests and demonstrates the test to be highly accurate in terms of both sensitivity and specificity. The overall average sensitivity of using cffDNA to determine fetal sex is $96.6 \%$ and the overall specificity is $98.9 \%$. These vary very little with trimester or week of testing, indicating that the performance of the test is reliably high. The most commonly used method for detection and identification of cffDNA

Table 1 Summary sensitivity and specificity based on bivariate model with no covariates

\begin{tabular}{|c|c|c|c|c|c|}
\hline Data & & $\begin{array}{r}\text { Median Sensitivity } \\
(95 \% \mathrm{Cl})[95 \% \mathrm{PI}]\end{array}$ & $\begin{array}{l}\text { Median specificity } \\
(95 \% \mathrm{CI})[95 \% \mathrm{PI}]\end{array}$ & $\begin{array}{c}\text { Heterogeneity SD } \\
\text { on logit } \\
\text { scale (sens) }\end{array}$ & $\begin{array}{l}\text { Heterogeneity } \\
\text { SD on logit } \\
\text { scale (spec) }\end{array}$ \\
\hline $\begin{array}{l}\text { Primary analysis } \\
\text { ( } n=10,587,90 \text { studies) }\end{array}$ & & $96.6(95.2,97.7)[64.4,99.8]$ & $98.9(98.1,99.4)[75.8,100.0)$ & 1.4 & 1.7 \\
\hline \multirow[t]{3}{*}{$\begin{array}{l}\text { Breakdown by trimester } \\
\text { ( } n=4,467,35 \text { studies })\end{array}$} & $\begin{array}{l}\text { First trimester } \\
(n=2,244,26 \text { studies) }\end{array}$ & $95.0(92.2,97.3)[71.7,99.4]$ & $98.8(97.0,99.7)[64.0,100.0)$ & 1.0 & 1.7 \\
\hline & $\begin{array}{l}\text { Second trimester } \\
\text { ( } n=1,662,15 \text { studies })\end{array}$ & $98.2(95.2,99.6)[64.9,100.0]$ & $99.5(98.2,100.0)[77.0,100]$ & 1.6 & 1.6 \\
\hline & $\begin{array}{l}\text { Third trimester } \\
\text { ( } n=561,9 \text { studies) }\end{array}$ & $96.6(86.6,99.7)[28.0,100.0]$ & $99.0(95.4,99.9)[70.6,100.0]$ & 1.8 & 1.3 \\
\hline
\end{tabular}

$\mathrm{Cl}=$ credible interval.

$\mathrm{PI}=$ prediction interval.

$\mathrm{SD}=$ standard deviation. 
specific to the $\mathrm{Y}$ chromosome was qPCR, which demonstrated increased specificity when compared with other methods. A number of Y chromosome markers are available for detection purposes. Our analyses did not show a discernable difference between SRY and DYS14, but did suggest that these lead to slightly better specificity than the other markers that had been used in the studies. The majority of studies also used fetal DNA extracted from plasma, and there is some evidence that using fetal DNA extracted from serum may produce slightly higher sensitivity and specificity. However, although these findings produced statistically significant $95 \%$ credible intervals, the confidence intervals were very wide and so we would caution against over-interpretation of the findings. Previous work has shown that similar levels of cffDNA are detected in both plasma and serum [4] and laboratories often use automated and optimized methods for DNA extraction regardless of whether they use serum or plasma. Laboratories are also likely to try both the DYS and SRY markers and settle with the marker that gives them the most reliable and reproducible result in their setting.

When compared to the systematic review and metaanalysis published recently by Devaney et al. [11] the current review utilized data on an additional 33 studies and $\sim 3,500$ pregnancies (90 studies v 57 studies and 9,965 pregnancies $\mathrm{v}$ 6,541 pregnancies). Both reviews show test performance to be reliably high with the increase in data presented in the current review showing small increases in both sensitivity (96.6\% compared with Devaney's 95.4\%) and specificity (98.9\% compared with Devaney's 98.6\%).

One limitation of this study was our inability to properly evaluate the proportion of inconclusive or uncertain results, which we know to be problematic with this technique and may vary with gestational age $[7,104]$. However, in the case of an inconclusive test result performed early in pregnancy, it would still be possible to retest at a later date. In addition, all literature-based reviews are at risk of publication bias due to the suppression of unwanted findings. We searched extensively for studies and contacted experts in the area, but cannot rule out the possibility that our sample of studies is not fully representative.

The main implications for this test in relation to the current clinical pathway would be that invasive testing can be avoided in the case of a diagnosed female fetus. If a female were to be incorrectly classified as male (false positive), there would be no change to the current clinical pathway. If a male fetus is incorrectly classified as a female (false negative), or if a fetus is unclassified after the first test, then invasive testing would be delayed potentially resulting in reduced quality of care.
Genetic testing of DNA extracted by amniocentesis or chorionic villus sampling is currently routine for prenatal testing. Both of these procedures take place later in pregnancy than would be required by a methods using cffDNA, and both carry a small but significant risk of miscarriage, something that cffDNA does not. The results of both this review and meta-analysis and the analysis by Devaney et al. [11] show that the diagnostic test of fetal sex determination using cffDNA is expected to be close to $100 \%$, it can be done early in pregnancy, and that the test itself carries no risk of miscarriage suggesting that we should seriously consider adopting this test as the new gold standard first-line test for pregnancies at risk of an X-linked condition. The test has been successfully used from 7 weeks of gestation in some NHS laboratories in the UK since 2003 following audit results $[104,105]$, where it has already reduced the need for invasive diagnostic testing in high risk pregnancies.

\section{Conclusions}

Based on the updated data provided in this review and meta-analysis we conclude that fetal sex can be determined with a high level of accuracy by analyzing cffDNA after 5 weeks of gestation. It is hoped that use of this method for non-invasive prenatal diagnosis could also be extended for single gene disorders and although testing is being developed, it is not currently offered on any routine basis within Europe. Advances in genomic methodology and technology continue to make tremendous progress and these advances need faster and timelier translation into clinical practice in order to provide couples with greater reproductive choice. Further research is needed into the logistical requirements, the economic considerations (including a possible value of information analysis) and the ethical implications of offering an early non-invasive test for fetal sex [106].

\section{Additional files}

Additional file 1: Prisma 2009 Checklist.

Additional file 2: Search terms as used in PubMed to search MEDLINE. 2). Table S1: Studies identified in this review and their main characteristics, ordered by year of publication. 3) Table S2: Summary statistics from posterior distributions from bivariate meta-regression analysis investigating the effect of week of test (standardized). 4) Table S3: Summary statistics from posterior distributions from bivariate meta-regression analyses using all studies ( $n=$ number of $2 \times 2$ tables constructed from included studies).

\section{Competing interests}

There are no competing interests.

\section{Authors' contributions}

CFW: design of study, collection and interpretation of data, writing of manuscript. YW: analysis and interpretation of data, writing of manuscript. JPTH: design of study, analysis and interpretation of data, writing of manuscript. GSS: design of study, collection and interpretation of data, 
writing and finalization of manuscript. All authors are in agreement with the final version of the manuscript.

\section{Acknowledgements}

CFW and GSS were supported by the PHG Foundation. The PHG Foundation is the working name of the Foundation for Genomics and Population Health, a charitable company registered in England and Wales: Charity No 118664, Company No 5823194. JPTH and YW were supported by MRC grant U.1052.00.011. We thank Dr Hilary Burton for helpful comments on the manuscript and the entire Working Group involved in the PHG Foundation project on non-invasive diagnosis (full list available at http://www. phgfoundation.org/reports/4985/). We are also grateful to the editorial staff of the Cochrane Pregnancy and Childbirth Group and the Cochrane Diagnostic Test Accuracy Editorial Team for helpful suggestions on an early version of the protocol for this review.

\section{Author details}

${ }^{1}$ PHG Foundation, 2 Worts Causeway, Cambridge, UK. ${ }^{2}$ MRC Biostatistics Unit, Institute of Public Health, Robinson Way, Cambridge, UK.

Received: 9 March 2012 Accepted: 14 August 2012

Published: 1 September 2012

\section{References}

1. Baird PA, Anderson TW, Newcombe HB, Lowry RB: Genetic disorders in children and young adults: a population study. Am J Hum Genet 1988, 42(5):677-693.

2. Mujezinovic F, Alfirevic Z: Procedure-related complications of amniocentesis and chorionic villous sampling: a systematic review. Obstet Gynecol 2007, 110(3):687-694.

3. Lo YM, Corbetta N, Chamberlain PF, Rai V, Sargent IL, Redman CW, et al: Presence of fetal DNA in maternal plasma and serum. Lancet 1997, 350(9076):485-487

4. Lo YM, Tein MS, Lau TK, Haines CJ, Leung TN, Poon PM, et al: Quantitative analysis of fetal DNA in maternal plasma and serum: implications for noninvasive prenatal diagnosis. Am J Hum Genet 1998, 62(4):768-775.

5. Lo YM, Zhang J, Leung TN, Lau TK, Chang AM, Hjelm NM: Rapid clearance of fetal DNA from maternal plasma. Am J Hum Genet 1999, 64(1):218-224.

6. Lo YM, Chan KC, Sun H, Chen EZ, Jiang P, Lun FM, Lo YM, Chan KC, Sun H, Chen EZ, Jiang P, Lun FM, et al: Maternal plasma DNA sequencing reveals the genome-wide genetic and mutational profile of the fetus. Sci Trans/ Med 2010, 2(61):61ra91.

7. Chitty L, Mistry B, Hogg J, Meaney C, Thomasson L, Norbury G, et al: Prospective Register of Oucomes Of Free-fetal DNA testing (PROOF) - results of the first year's audit. Newsletter of the British Society for Human Genetics 2007, 37(November):8-9.

8. Galbiati S, Smid M, Gambini D, Ferrari A, Restagno G, Viora E, et al: Fetal DNA detection in maternal plasma throughout gestation. Hum Genet 2005, 117(2-3):243-248.

9. Sekizawa A, Kondo T, Iwasaki M, Watanabe A, Jimbo M, Saito H, et al: Accuracy of fetal gender determination by analysis of DNA in maternal plasma. Clin Chem 2001, 47(10):1856-1858.

10. Avent ND, Chitty LS: Non-invasive diagnosis of fetal sex; utilization of free fetal DNA in maternal plasma and ultrasound. Prenat Diagn 2006, 26(7):598-603

11. Devaney SA, Palomaki GE, Scott JA, Bianchi DW: Noninvasive fetal sex determination using cell-free fetal DNA: A systematic review and meta-analysis. JAMA 2011, 306(6):627-636.

12. Chiu RW, Chan KC, Gao Y, Lau VY, Zheng W, Leung TY, et al: Noninvasive prenatal diagnosis of fetal chromosomal aneuploidy by massively parallel genomic sequencing of DNA in maternal plasma. Proc Natl Acad Sci USA 2008, 105(51):20458-20463.

13. Fan HC, Blumenfeld YJ, Chitkara U, Hudgins L, Quake SR: Noninvasive diagnosis of fetal aneuploidy by shotgun sequencing DNA from maternal blood. Proc Natl Acad Sci USA 2008, 105(42):16266-16271.

14. Deeks JJ, Bossuyt PM, Gatsonis CE: Cochrane Handbook for Systematic Reviews of Diagnostic Test Accuracy Version 1.0. The Cochrane Collaboration: 2010. Available from http://srdta.cochrane.org Accessed.

15. Reitsma JB, Glas AS, Rutjes AW, Scholten RJ, Bossuyt PM, Zwinderman AH: Bivariate analysis of sensitivity and specificity produces informative summary measures in diagnostic reviews. J Clin Epidemiol 2005, 58(10):982-990.

16. Riley RD, Higgins JPT, Deeks JJ: Interpretation of random effects meta-analyses. BMJ 2011, 342:d549.

17. Thompson SG: Controversies in meta-analysis: the case of the trials of serum cholesterol reduction. Stat Methods Med Res 1993, 2(2):173-192.

18. Lunn DJ, Thomas A, Best N, Spiegelhalter D: WinBUGS a Bayesian modelling framework: concepts, structure, and extensibility. Statistics and Computing 2000, 10:325-337.

19. Review Manager (RevMan) [Computer program]. Version 5.0: The Cochrane Collaboration. Copenhagen: The Nordic Cochrane Centre; 2008.

20. Lazaros L, Hatzi E, Bouba I, Makrydimas G, Dalkalitsis N, Stefos T, et al: Non-invasive first-trimester detection of paternal beta-globin gene mutations and polymorphisms as predictors of thalassemia risk at chorionic villous sampling. Eur J Obstet Gynecol Reprod Biol 2008, 140(1):17-20.

21. Bischoff FZ, Sinacori MK, Dang DD, Marquez-Do D, Horne C, Lewis DE, et al: Cell-free fetal DNA and intact fetal cells in maternal blood circulation: implications for first and second trimester non-invasive prenatal diagnosis. Hum Reprod Update 2002, 8(6):493-500.

22. Johnson KL, Dukes KA, Vidaver J, Leshane ES, Ramirez I, Weber WD, et al: Interlaboratory Comparison of Fetal Male DNA Detection from Common Maternal Plasma Samples by Real-Time PCR. Clin Chem 2004, 50(3):516-521.

23. Honda $H$, Miharu $N$, Ohashi $Y$, Samura O, Kinutani M, Hara T, et al: Fetal gender determination in early pregnancy through qualitative and quantitative analysis of fetal DNA in maternal serum. Hum Genet 2002, 110(1):75-79.

24. Deng Z, Wu G, Li Q, Zhang X, Liang Y, Li D, et al: Noninvasive genotyping of 9 Y-chromosome specific STR loci using circulatory fetal DNA in maternal plasma by multiplex PCR. Prenatal Diag 2006, 26(4):362-368.

25. Zhong $X Y$, Holzgreve $W$, Hahn S: Detection of fetal Rhesus $D$ and sex using fetal DNA from maternal plasma by multiplex polymerase chain reaction. BJOG 2000, 107(6):766-769.

26. Randon I, Hauge R, Kjeldsen-ragh J, Fagerhol MK: Prenatal genotyping of RHD and SRY using maternal blood. Vox Sang 2003, 85(4):300-306.

27. Zimmermann B, El Sheikhah A, Nicolaides K, Holzgreve W, Hahn S: Optimized Real-Time Quantitative PCR Measurement of Male Fetal DNA in Maternal Plasma. Clin Chem 2005, 51(9):1598-1604.

28. Tungwiwat W, Fucharoen S, Fucharoen G, Ratanasiri T, Sanchaisuriya K: Accuracy of fetal gender detection using a conventional nested PCR assay of maternal plasma in daily practice. Aust N Z J Obstet Gynaecol 2008, 48(5):501-504

29. Smid M, Lagona F, de Benassuti L, Ferrari A, Ferrari M, Cremonesi L: Evaluation of Different Approaches for Fetal DNA Analysis from Maternal Plasma and Nucleated Blood Cells. Clin Chem 1999, 45(9):1570-1572.

30. Hromadnikova I, Houbova B, Hridelova D, Voslarova S, Calda P, Nekolarova $K$, et al: Quantitative analysis of DNA levels in maternal plasma in normal and Down syndrome pregnancies. BMC Pregnancy Childbirth 2002, 2:4-9.

31. Vodicka R, Vrtel R, Schneiderova E, Vrbicka D, Prochazka M, Dhaifalah I, et al: Noninvasive fetal sex detection from maternal plasma in pregnant women. Ceska Gynekol 2008, 73(3):150-153.

32. Picchiassi E, Coata G, Fanetti A, Centra M, Pennacchi L, Di Renzo GC: The best approach for early prediction of fetal gender by using free fetal DNA from maternal plasma. Prenat Diagn 2008, 28(6):525-530.

33. Martinhago CD, de Oliveira RM, Canas MCT, Vagnini LD, Oliveira JBA Petersen $C_{G}$, et al: Accuracy of fetal gender determination in maternal plasma at 5 and 6 weeks of pregnancy. Prenatal Diag 2006, 26:1219-1223.

34. Chen ZB, Yan M, Lei Z, Xiao B, Liang Y, Zhu ZL, et al: Application of fetal DNA in maternal plasma for non-invasive prenatal diagnosis of fetal sex. Yi Chuan 2004, 26(1):18-22

35. Costa JM, Ernault P, Olivi M, Gaillon T, Arar K: Chimeric LNA/DNA probes as a detection system for real-time PCR. Clin Biochem 2004, 37(10):930-932.

36. Leung TN, Zhang J, Lau TK, Hjelm NM, Lo YMD: Maternal plasma fetal DNA as a marker for preterm labour. Lancet 1998, 352(9144):1904-1905.

37. Minon JM, Gerard C, Senterre JM, Schaaps JP, Foidart JM: Routine fetal RHD genotyping with maternal plasma: a four-year experience in Belgium. Transfusion 2008, 48(2):373-381.

38. Atamaniuk J, Stuhlmeier KM, Karimi A, Mueller MM: Comparison of PCR methods for detecting fetal RhDin maternal plasma. J Clin Lab Anal 2009, 23(1):24-28. 
39. Bustamante-Aragones A, Rodrigez De Alba M, Gonzalez-Gonzalez C, Trujillo-Tiebas MJ, Diego-Alvarez D, Vallespin E, et al: Foetal sex determination in maternal blood from the seventh week of gestation and its role in diagnosing haemophilia in foetuses of female carriers. Haemophilia 2008, 14:593-598.

40. Lapaire O, Volgmann T, Grill S, Hosli I, Zanetti-Daellenbach R, Zhong XY, et al: Significant correlation between maternal body mass index at delivery and in the second trimester, and second trimester circulating total cell-free DNA levels. Reprod Sci 2009, 16(3):274-279.

41. Sesarini C, Gimenez ML, Redal MA, Izbizky G, Aiello H, Argibay P, et al: Non invasive prenatal genetic diagnosis of fetal $\mathrm{RhD}$ and sex through the analysis of free fetal DNA in maternal plasma. Arch Argent Pediatr 2009, 107(5):405-409.

42. Sikora A, Zimmermann BG, Rusterholz C, Birri D, Kolla V, Lapaire O, et al: Detection of increased amounts of cell-free fetal DNA with short PCR amplicons. Clin Chem 2010, 56(1):136-138.

43. Vora NL, Johnson KL, Peter I, Tighiouart H, Ralston SJ, Craigo SD, et al: Circulating cell-free DNA levels increase variably following chorionic villus sampling. Prenat Diagn 2010, 30(4):325-328.

44. Wang XD, Wang BL, Ye SL, Liao YQ, Wang LF, He ZM: Non-invasive foetal RHD genotyping via real-time PCR of foetal DNA from Chinese RhD-negative maternal plasma. Eur J Clin Invest 2009, 39(7):607-617.

45. Al Yatama MK, Mustafa AS, Ali S, Abraham S, Khan Z, Khaja N: Detection of $Y$ chromosome-specific DNA in the plasma and urine of pregnant women using nested polymerase chain reaction. Prena. Diagn 2001, 21(5):399-402

46. Illanes S, Denbow ML, Smith RP, Overton TG, Soothill PW, Finning K: Detection of cell-free fetal DNA in maternal urine. Prenat Diagn 2006, 26(13):1216-1218.

47. Li Y, Holzgreve W, Kiefer V, Hahn S: MALDI-TOF mass spectrometry compared with real-time PCR for detection of fetal cell-free DNA in maternal plasma. Clin Chem 2006, 52(12):2311-2312.

48. Zhong $X Y$, Hahn S, Holzgreve W: Prenatal identification of fetal genetic traits. Lancet 2001, 357(9252):310-331.

49. Alberry M, Maddocks D, Jones M, Abdel HM, Abdel-Fattah S, Avent N, et al Free fetal DNA in maternal plasma in anembryonic pregnancies: confirmation that the origin is the trophoblast. Prenat Diagn 2007 27(5):415-418.

50. Benachi A, Steffann J, Gautier E, Ernault P, Olivi M, Dumez Y, et al: Fetal DNA in maternal serum: does it persist after pregnancy? Hum Genet 2003, 113(1):76-79.

51. Bischoff FZ, Dang DX, Marquez-Do D, Martinez D, Horne C, Lewis DE, et al: Detecting fetal DNA from dried maternal blood spots: another step towards broad scale non-invasive prenatal genetic screening and feasible testing. Reprod Biomed Online 2003, 6(3):349-351.

52. Boon EM, Schlecht HB, Martin P, Daniels G, Vossen RH, den Dunnen JT, et al: Y chromosome detection by Real Time PCR and pyrophosphorolysis-activated polymerisation using free fetal DNA isolated from maternal plasma. Prenat Diagn 2007, 27(10):932-937.

53. Brojer E, Zupanska B, Guz K, Orzinska A, Kalinska A: Noninvasive determination of fetal RHD status by examination of cell-free DNA in maternal plasma. Transfusion 2005, 45(9):1473-1480.

54. Chan KC, Zhang J, Hui AB, Wong N, Lau TK, Leung TN, et al: Size distributions of maternal and fetal DNA in maternal plasma. Clin Chem 2004, 50(1):88-92.

55. Chen H, Wang T, He G, Zhu L, Ma T: Gene analysis of free fetal DNA in maternal plasma. J Tongii Med Univ 2001, 21(4):329-331.

56. Chen HP, Wang TR, Xu JP, Xu XY, Dangol SD, He GF: Fetal origin of single nucleated erythroblasts and free DNA in the peripheral blood of pregnant women. Int J Gynecol Obstet 2004, 85(1):1-5.

57. Chi C, Hyett JA, Finning KM, Lee CA, Kadir RA: Non-invasive first trimester determination of fetal gender: a new approach for prenatal diagnosis of haemophilia. BJOG 2006, 113(2):239-242.

58. $\mathrm{Chi} \mathrm{H}$, Kang Z, Hu G: Detection of fetal DNA in maternal plasma using the nested polymerase chain reaction. Zhonghua Fu Chan Ke Za Zhi 1999, 34(1):27-29

59. Costa JM, Benachi A, Gautier E, Jouannic JM, Ernault P, Dumez Y: First-trimester fetal sex determination in maternal serum using real-time PCR. Prenat Diagn 2001, 21(12):1070-1074.

60. Cremonesi L, Galbiati S, Foglieni B, Smid M, Gambini D, Ferrari A, et al: Feasibility study for a microchip-based approach for noninvasive prenatal diagnosis of genetic diseases. Ann N Y Acad Sci 2004, 1022:105-112

61. Davalieva K, Dimcev P, Efremov GD, Plaseska-Karanfilska D: Non-invasive fetal sex determination using real-time PCR. J Matern Fetal Neonatal Med 2006, 19(6):337-342.

62. Falcinelli C, Battafarano S, Neri C, Mazza V, Ranzi A, Volpe A, et al: First-trimester fetal sex prediction by deoxyribonucleic acid analysis of maternal peripheral blood. Am J Obstet Gynecol 1999, 181(3):675-680.

63. Vecchione G, Tomaiuolo M, Sarno M, Colaizzo D, Petraroli R, Matteo M, et al: Fetal sex identification in maternal plasma by means of short tandem repeats on chromosome x. Ann N Y Acad Sci 2008, 1137:148-156.

64. Guibert J, Benachi A, Grebille AG, Ernault P, Zorn JR, Costa JM: Kinetics of SRY gene appearance in maternal serum: detection by real time PCR in early pregnancy after assisted reproductive technique. Hum Reprod 2003, 18(8):1733-1736.

65. Houfflin-Debarge V, O'Donnell H, Overton T, Bennett PR, Fisk NM: High sensitivity of fetal DNA in plasma compared to serum and nucleated cells using unnested PCR in maternal blood. Fetal Diagn Ther 2000, 15(2):102-107

66. Hromadnikova I, Houbova B, Hridelova D, Voslarova S, Kofer J, Komrska V, et al: Replicate real-time PCR testing of DNA in maternal plasma increases the sensitivity of non-invasive fetal sex determination. Prenat Diagn 2003, 23(3):235-238.

67. Hyett JA, Gardener G, Stojilkovic-Mikic T, Finning KM, Martin PG, Rodeck CH, et al: Reduction in diagnostic and therapeutic interventions by noninvasive determination of fetal sex in early pregnancy. Prenat Diagn 2005, 25(12):1111-1116.

68. Illanes S, Denbow M, Kailasam C, Finning K, Soothill PW: Early detection of cell-free fetal DNA in maternal plasma. Early Hum Dev 2007, 83(9):563-566.

69. Lapaire OM, Volgmann TM, Huang DM, Hahn S, Holzgreve W, Xiao Zhong YM: Maternal Smoking: Effect on Circulating Cell-Free Fetal and Total DNA Levels in Maternal Plasma From the Second Trimester. Obstet Gynecol 2007, 110(6):1358-1363.

70. Lazar L, Ban Z, Szakacs O, Nagy B, Beke A, Oroszne NJ, et al: Fetal sex determination with real time PCR of fetal DNA in maternal plasma. Orv Hetil 2003, 144(49):2405-2409.

71. Majer S, Bauer M, Magnet E, Strele A, Giegerl E, Eder M, et al: Maternal urine for prenatal diagnosis-an analysis of cell-free fetal DNA in maternal urine and plasma in the third trimester. Prenat Diagn 2007 27(13):1219-1223.

72. Mazza V, Falcinelli C, Percesepe A, Paganelli S, Volpe A, Forabosco A: Non-invasive first trimester fetal gender assignment in pregnancies at risk for X-linked recessive diseases. Prenat Diagn 2002, 22(10):919-924.

73. Rijnders RJ, Van Der Luijt RB, Peters ED, Goeree JK, Van Der Schoot CE, Ploos Van Amstel JK, et al: Earliest gestational age for fetal sexing in cell-free maternal plasma. Prenat Diagn 2003, 23(13):1042-1044

74. Rijnders RJ, Christiaens GC, Bossers B, van der Smagt JJ, Van Der Schoot CE, de Haas M: Clinical applications of cell-free fetal DNA from maternal plasma. Obstet Gynecol 2004, 103(1):157-164

75. Rijnders RJP, van der Schoot CE, Bossers B, de Vroede MAMJ, Christiaens GCML: Fetal sex determination from maternal plasma in pregnancies at risk for congenital adrenal hyperplasia. Obstet Gynecol 2001, 98(3):374-378

76. Smid M, Lagona F, Papasergio N, Ferrari A, Ferrari M, Cremonesi L: Influence of gestational age on fetal deoxyribonucleic acid retrieval in maternal peripheral blood. Am J Obstet Gynecol 1997, 177(6):1517-1522.

77. Stanghellini I, Bertorelli R, Capone L, Mazza V, Neri C, Percesepe A, et al: Quantitation of fetal DNA in maternal serum during the first trimester of pregnancy by the use of a DAZ repetitive probe. Mol Hum Reprod 2006, 12(9):587-591.

78. Tachdjian G, Frydman N, Audibert F, Ray P, Kerbrat V, Ernault P, et al: Clinical applications of fetal sex determination in maternal blood in a preimplantation genetic diagnosis centre. Hum Reprod 2002, 17(8):2183-2186

79. Zhong XY, Burk MR, Troeger C, Kang A, Holzgreve W, Hahn S: Fluctuation of maternal and fetal free extracellular circulatory DNA in maternal plasma. Obstet Gynecol 2000, 96(6):991-996.

80. Zhong $X Y$, Holzgreve $W$, Hahn S: Risk free simultaneous prenatal identification of fetal Rhesus D status and sex by multiplex real-time PCR using cell free fetal DNA in maternal plasma. Swiss Med Wkly 2001, 131(5-6):70-74. 
81. Zhong XY, Holzgreve W, Tercanli S, Wenzel F, Hahn S: Cell-free foetal DNA in maternal plasma does not appear to be derived from the rich pool of cell-free foetal DNA in amniotic fluid. Arch Gynecol Obstet 2006, 273(4):221-226

82. Ge Q, Bai Y, Liu Z, Liu Q, Yan L, Lu Z: Detection of fetal DNA in maternal plasma by microarray coupled with emulsions PCR. Clin Chim Acta 2006, 369(1):82-88.

83. Ho SS, Damayanti Z, Chua WY, Ng BL, Peh CM, Biswas A, et al: Non-invasive prenatal diagnosis of fetal gender using real-time polymerase chain reaction amplification of SRY in maternal plasma. Ann Acad Med Singapore 2004, 33(5 Suppl):S61-S62.

84. Honda H, Miharu N, Ohashi Y, Ohama K: Successful diagnosis of fetal gender using conventional PCR analysis of maternal serum. Clin Chem 2001, 47(1):41-46.

85. Hong P, Zhu PY, Huang YF, Luan JF: Study on fetal SRY gene in maternal plasma using nested polymerase chain reaction. Zhonghua Nan Ke Xue 2006, 12(4):333-336

86. Hwa HL, Ko TM, Yen ML, Chiang YL: Fetal gender determination using real-time quantitative polymerase chain reaction analysis of maternal plasma. J Formos Med Assoc 2004, 103(5):364-368.

87. Jorgez CJ, Dang DD, Simpson JL, Lewis DE, Bischoff FZ: Quantity versus quality: optimal methods for cell-free DNA isolation from plasma of pregnant women. Genet Med 2006, 8(10):615-619.

88. Kimura M, Sato C, Hara M, Ishihara O, Ikebuchi K: Noninvasive fetal RHD genotyping by maternal plasma with capillary electrophoresis. Transfusion 2008, 48(6):1156-1163

89. Liu FM, Wang $X Y$, Feng $X$, Wang $W$, Ye $Y X$, Chen $H$ : Feasibility study of using fetal DNA in maternal plasma for non-invasive prenatal diagnosis. Acta Obstet Gynecol Scand 2007, 86(5):535-541.

90. Lo YM, Lau TK, Zhang J, Leung TN, Chang AM, Hjelm NM, et al: Increased fetal DNA concentrations in the plasma of pregnant women carrying fetuses with trisomy 21. Clin Chem 1999, 45(10):1747-1751.

91. Pertl B, Sekizawa A, Samura O, Orescovic I, Rahaim PT, Bianchi DW Detection of male and female fetal DNA in maternal plasma by multiplex fluorescent polymerase chain reaction amplification of short tandem repeats. Hum Genet 2000, 106(1):45-49.

92. Ren CC, Wang WJ, Liu GC, Zhang HX, Xu YF, Tang ZM, et al: Detection of fetal SRY gene in maternal plasma by real-time fluorescence quantitative PCR. Zhonghua Yi Xue Yi Chuan Xue Za Zhi 2004, 21(4):386-388.

93. Ren CC, Miao XH, Cheng $H$, Chen L, Song WQ: Detection of fetal sex in the peripheral blood of pregnant women. Fetal Diagn Ther 2007, 22(5):377-382

94. SantacroceE R, Vecchione G, Tomaiyolo M, Sessa F, Sarno M, Collaizzo D, et al: Identification of fetal gender in maternal blood is a helpful tool in the prenatal diagnosis of haemophilia. Haemophilia 2006, 12(4):417-422.

95. Siva SC, Johnson SI, McCracken SA, Morris JM: Evaluation of the clinical usefulness of isolation of fetal DNA from the maternal circulation. Aust $N$ Z J Obstet Gynaecol 2003, 43(1):10-15.

96. Tungwiwat W, Fucharoen G, Ratanasiri T, Sanchaisuriya K, Fucharoen S: Non-invasive fetal sex determination using a conventional nested PCR analysis of fetal DNA in maternal plasma. Clin Chim Acta 2003, 334(1-2):173-177.

97. Urato AC, Peter I, Canick J, Lambert-Messerlian G, Pulkkinen A, Knight G, et al: Smoking in pregnancy is associated with increased total maternal serum cell-free DNA levels. Prenat Diagn 2008, 28:186-190.

98. Wagner J, Dzijan S, Pavan-Jukic D, Wagner J, Lauc G: Analysis of multiple loci can increase reliability of detection of fetal Y-chromosome DNA in maternal plasma. Prenat Diagn 2008, 28(5):412-416.

99. Wei C, Saller DN, Sutherland JW: Detection and quantification by homogeneous PCR of cell-free fetal DNA in maternal plasma. Clin Chem 2001, 47(2):336-338.

100. Zhao XX, Suzumori N, Ozaki Y, Sato T, Suzumori K: Examination of fetal cells and cell-free fetal DNA in maternal blood for fetal gender determination. Gynecol Obstet Invest 2004, 58(1):57-60.

101. Zhao Y, Zou L: Application of fetal DNA in maternal plasma in noninvasive prenatal diagnosis. J Huazhong Univ Sci Technolog Med Sci 2004, 24(1):59-61.

102. Zhu B, Sun QW, Lu YC, Sun MM, Wang $L$, Huang XH: Prenatal fetal sex diagnosis by detecting amelogenin gene in maternal plasma. Prenat Diagn 2005, 25(7):577-581.
103. Zolotukhina TV, Shilova NV, Voskoboeva EY: Analysis of cell-free fetal DNA in plasma and serum of pregnant women. J Histochem Cytochem 2005, 53(3):297-299

104. Hill M, Finning K, Martin P, Hogg J, Meaney C, Norbury G, et al: Non-invasive prenatal determination of fetal sex: translating research into clinical practice. Clin Genet 2011, 80(1):68-75.

105. Raymond FL, Whittaker J, Jenkins L, Lench N, Chitty LS: Molecular prenatal diagnosis: the impact of modern technologies. Prenat Diagn 2010, 30(7):674-681.

106. Hall A, Bostanci A, Wright CF: Non-invasive prenatal diagnosis using cell-free fetal DNA technology: applications and implications. Public Health Genomics 2010, 13(4):246-255.

doi:10.1186/1756-0500-5-476

Cite this article as: Wright et al:: Non-invasive prenatal diagnostic test accuracy for fetal sex using cell-free DNA a review and meta-analysis. BMC Research Notes 2012 5:476.

\section{Submit your next manuscript to BioMed Central and take full advantage of:}

- Convenient online submission

- Thorough peer review

- No space constraints or color figure charges

- Immediate publication on acceptance

- Inclusion in PubMed, CAS, Scopus and Google Scholar

- Research which is freely available for redistribution 